\title{
Characterization of Colorimetric Parameters in Cattle Meat
}

\author{
Nicoleta GĂINĂ (DIACONU)*, Roxana LAZĂR, Emanuiel C. DIACONU, Marius M. CIOBANU, \\ Paul C. BOIŞTEANU
}

Department of Fundamental Sciences in Animal Husbandry, University of Agricultural Sciences and Veterinary Medicine Iaşi, Romania

*Corresponding author, email: diaconunico19@yahoo.com

Bulletin UASVM Animal Science and Biotechnologies 71(2) / 2014,

Print ISSN 1843-5262; Electronic ISSN 1843-536X

DOI: 10.15835/buasvmcn-asb:10468

\begin{abstract}
Color is one of the most important sensory parameters of meat, because for the consumers is the first indicator of its freshness.

Color allows detection of anomalies or the presence of defects in the meat. It was found that the equipment and methodology for measuring color is available from the economic point of view and allow the improvement of food products.

The purpose of this paper is to evaluate the color of muscle tissue from cattle slaughtered in our country by using colorimetric scale CIE L*a*b*.

Color values were measured using the Minolta spectrophotometer CM $2600 \mathrm{~d}$, and the samples under study are represented by three types of muscle tissues from five randomly selected cattle from the slaughter technological flow (Longissimus dorsi thoracis, Longissimus dorsi lumborum, Psoas Minor and Major)

The results obtained from measurements performed on the three muscle areas showed that physical activity performed by live animal have influence over anatomical region of origin of the muscle, and therefore on its color. Thus M.Psoas has the lowest averages of the three features- $\mathrm{L}^{*}(30.39 \pm 0.86), \mathrm{a}^{*}(10.73 \pm 0.51)$ and $\mathrm{b}^{*}(11.29 \pm 0.91)$.

These results are relevant for determining the quality and safety of meat, bringing support to consumer in choosing a particular type of meat. Also helps to improve pre slaughtering and post slaughtering practices, operations that interact on the biochemical processes taking place in the animal body, and provides sensory physical and chemical characteristics, superior qualitative.
\end{abstract}

Keywords: cattle, color, freshness

\section{INTRODUCTION}

Antonio Girolami et al. (2013) noted that the first assessment of the consumer impression of a food is perceived by the visual analyzer, which is mainly related to the aspect. Thus, visual perception of color, the form of food can affect expectations about other organoleptic characteristics (taste, smell, etc.).

For meat, the color is one of the most important organoleptic characteristics because have a great influence over consumer decisions in purchasing (Mancini \& Hunt, 2005), which associate the color with freshness of meat.
Priolo et al. (2001) mentions that a number of factors such as enzymes, animal age, their nutrition, physiological activities during their life and storage conditions after slaughtering can affect the color of the meat.

In the raw composition of meat myoglobin appears in three different forms: deoxymyoglobin (DMB), oxymyoglobin (OMB) and methmyoglobin (MMB). A low pressure of oxygen favors the presence in the blood of DMB (dark red color), while a high pressure causes the conversion of myoglobin to oxymyoglobin, being responsible for the bright red color of meat. 
Light exposure of meat influence the enhanced formation of the MMB on its surface, distorting color during prolonged storage.

Zhang et al. (2005) found that a meat that has high $\mathrm{pH}$ values gave low color coordinates, which suggests that elevated $\mathrm{pH}$ gives to meat tissues a darker color. Also, animals that are fed into the system freely on pasture provide fat in shades of yellow colors, due to the high content of beta-carotene from green table. Consumers often perceive meat that has yellow fat as being old or from a sick animal. Meat has an inhomogeneous optical surface due to its structure, connective tissue and intramuscular fat.

It is well known that stressing cattle before slaughter depletes glycogen stores, which requires obtaining meat with a high $\mathrm{pH}$, especially in animals that are subjected to a poor diets nutritional point of view (Knee et al., 2007).

However, many studies show that cattle reared in loose housing (pasture) give a darker meat than those raised in closed systems, the explanation being due to the physical activity performed, age at slaughter, carcass weight and the amount of fat accumulated.

\section{MATERIALS AND METHODS}

The purpose of this paper is to evaluate the color of muscle tissue from cattle slaughtered in our country by using colorimetric scale CIE $\mathrm{L}^{*} \mathrm{a}^{*} \mathrm{~b}^{*}$ ( $\mathrm{L}^{*}$-the lightness, $\mathrm{a}^{*}$-redness and $\mathrm{b}^{*}$-yellowness).

For this study were collected three types of muscle tissue (Psoas M., Longissimus dorsi thoracis $M$. and Longissimus dorsi lumborum M.). They come from five randomly selected cattle slaughtered on the technological flow of a slaughterhouse from Botosani County.

Color values were measured using a spectrophotometer Minolta CM $2600 \mathrm{~d}$ with a $1 \mathrm{~cm}$ aperture, using Standard Illuminant D65 light source and 10 viewing angle geometry.

Tapp III WN et al. (2011) noted that the standard light source (D65) is used in most of the color measurements from the literature.

The CIE $L^{*} a^{*} b^{*}$ is an international standard for color measurement adopted by the International d'Eclairage (CIE) in 1976 (Oleari, 2008): L* is the lightness component, which ranges from 0 to 100 (from black to white) and the parameters $\mathrm{a}^{*}$ (green-negative, red-positive) and $\mathrm{b}^{*}$ (bluenegative, yellow-positive) are two chromatic ele- ments ranging from -120 to 120 (Papadakis et al., 2000).

Using spectrophotometers (NIRS - Near Infrared Spectrophotometers) can be a quick and effective control in the meat industry in order to assess its quality (Cozzolino et al., 2003).

\section{RESULTS AND DISCUSSION}

The results obtained from measurements performed on the three muscle areas showed that physical activity done by live animal influence the anatomical region from where muscle it comes and therefore on its color.

Meat color is influenced by a number of factors such as: content of enzymes, genotype, sex, diet and age of the animal. Myoglobin is fixed in tissue cells and has a purplish color. This is the protein that prints the red color of meat. In contact with oxygen, it becomes oxymyoglobin, which has deep red color, being measured objectively by the complementary coordinate "a *" (Priolo et al., 2001).

Regarding lightness parameter, Psoas muscle has its lowest average (30.39 \pm 0.86 units) compared with Longissimus dorsi lumborum and Longissimus dorsi thoracis muscles (Tab.1).

The oscillation of these values is mainly due to proportion between white and red fibers at the muscular tissue level and also due to age differences between cattle slaughtered.

Similar values were found in cattle meat by Chmiel et al. (2012) the averages obtained ranging so:

- L*(lightness): 29.5 - 39.8 units;

- a*(red - green): 7.1 - 19.2 units;

- b* (yellow - blue): $7.4-23.1$ units.

For the complementary colors - red-green ( $\left.\mathrm{a}^{*}\right)$ coordinate, the minimum values were recorded in the Psoas muscle (9.46 units) and the maximum (13.77 units) belonged to Longissimus dorsi lumborum muscle.

Significant differences in the red-green coordinates have been associated with the type and the proportion muscle fibers and connective tissue in the muscle, differentiated levels of glycogen stores, the amount of myoglobin, as well as the age at slaughter.

Averages calculated for complementary colors yellow - green coordinate $\left(b^{*}\right)$ varied within a range defined lower by Psoas $M$. with $11.29 \pm 0.91$ units, this one reaching a minimum value of 7.91, 
Tab. 1. Statistical estimators for colorimetric parameters at muscle tissue from cattle

\begin{tabular}{|c|c|c|c|c|c|c|c|}
\hline & \multirow[b]{2}{*}{ Specification } & \multirow[b]{2}{*}{ no } & \multicolumn{4}{|c|}{ Statistical indicators calculated } & \multirow{2}{*}{$\begin{array}{c}\text { Significance of } \\
\text { differences between the } \\
\text { averages of lots } \\
\text { (FISHER Test) }\end{array}$} \\
\hline & & & $\overline{\mathbf{x}} \pm s_{\overline{\mathbf{x}}}$ & V\% & Min. & Max. & \\
\hline \multirow{3}{*}{ ב- } & M. Psoas & \multirow{3}{*}{5} & $30.39 \pm 0.86$ & 6.39 & 27.23 & 32.03 & \multirow{3}{*}{$\begin{array}{c}\hat{\mathrm{F}}_{15.95}>\mathrm{F}_{0,001 \%}(12.97) \\
\rightarrow * * *\end{array}$} \\
\hline & $\begin{array}{c}\text { M. Longissimus dorsi } \\
\text { lumborum }\end{array}$ & & $35.58 \pm 0.60$ & 3.81 & 33.36 & 36.9 & \\
\hline & $\begin{array}{c}\text { M. Longissimus dorsi } \\
\text { thoracis }\end{array}$ & & $32.85 \pm 0.37$ & 2.55 & 31.83 & 33.96 & \\
\hline \multirow{3}{*}{ *๘ } & M. Psoas & \multirow{3}{*}{5} & $10.73 \pm 0.51$ & 10.70 & 9.46 & 12.15 & \multirow{3}{*}{$\begin{array}{c}\hat{\mathrm{F}}_{4.56}>\mathrm{F}_{0,05 \%}(3.88) \\
\rightarrow *\end{array}$} \\
\hline & $\begin{array}{l}\begin{array}{c}\text { M. Longissimus dorsi } \\
\text { lumborum }\end{array} \\
\end{array}$ & & $12.68 \pm 0.63$ & 11.16 & 10.59 & 13.77 & \\
\hline & $\begin{array}{c}\text { M. Longissimus dorsi } \\
\text { thoracis }\end{array}$ & & $12.42 \pm 0.27$ & 4.86 & 11.53 & 13.16 & \\
\hline \multirow{3}{*}{ • } & M. Psoas & \multirow{3}{*}{5} & $11.29 \pm 0.91$ & 18.08 & 7.91 & 13.09 & \multirow{3}{*}{$\begin{array}{c}\hat{\mathrm{F}}_{13.98}>\mathrm{F}_{0,001 \%}(12.97) \\
\rightarrow * * *\end{array}$} \\
\hline & $\begin{array}{c}\text { M. Longissimus dorsi } \\
\text { lumborum }\end{array}$ & & $15.82 \pm 0.61$ & 8.62 & 14.28 & 17.33 & \\
\hline & $\begin{array}{c}\text { M. Longissimus dorsi } \\
\text { thoracis }\end{array}$ & & $14.95 \pm 0.18$ & 2.72 & 14.64 & 15.63 & \\
\hline
\end{tabular}

$\mathrm{L}^{*}$-lightness, a*-redness, $\mathrm{b}^{*}$-yellowness.

and for the coordinated $b^{*}$ overview was found a superiority of values obtained by Longissimus dorsi lumborum muscle (17.33).

Following the calculation of this coordinate were recorded significant differences, variations due to distinct anatomical regions that have different functional and metabolic characteristics.

\section{CONCLUSION}

These results are relevant in determination of food quality and safety because supplemented and argues final consumer choice in choosing a particular type of meat and preferences on specific anatomical regions.

Acknowledgments. This paper was published under the frame of European Social Fund, Human Resources Development Operational Programme 2007-2013, projectno.POSDRU/159/1.5/S/132765.

\section{REFERENCES}

1. Chmiel M, Slowinski M, Dasiewicz $K$ and Florowski $T$ (2012). Application of a computer vision system to classify beef as normal or dark, firm, and dry, J ANIM SCI, 90:4126-4130.
2. Cozzolino D, Barlocco N, Vadell A, Ballesteros F, Gallieta G (2003). Vollume 36, Issue 2, Food Science and Technology, 195-202.

3. Girolami A, Napolitano F, Faraone D, Braghieri A (2013). Measurement of meat color using a computer vision system, Meat Science 93, 111-118.

4. Knee BW, Cummins LJ, Walker PJ, Kearney G, Warner RD (2007). Reducing dark-cutting in pasture-fed beef steers by high-energy supplementation. Australian Journal of Experimental Agriculture 47, 1277-1283. doi:10.1071/ EA05362.

5. Mancini RA \& Hunt MC (2005). Current research in meat color. Meat Science, 71,100-121.

6. Oleari C (2008). Misurare il colore (2nd ed.). Milano: Hoepli Editore (Chapters 2 and 6).

7. Papadakis SE, Abdul-Malek S, Kamdem RE \& Yam KL (2000). A versatile and inexpensive technique for measuring color of foods. Food Technology, 5(12), 48-51.

8. Priolo A, Micol D \& Agabriel J (2001). Effects of grass feeding systems on ruminant meat colour and flavour: A review. Animal Research, 50, 185-200.

9. Tapp III WN, Yancey JWS, Apple JK (2011). How is the instrumental color of meat measured? Meat Science, 89(1): 1-5.

10. Zhang SX, Farouk MM, Young OA, Wieliczko KJ \& Podmore C (2005). Functional stability of frozen normal and high pH beef. Meat Science, 69,765-772. 